\title{
SOLOMONA HILLERA MŪŽA METI UN PALIEKAMAIS DEVUMS ZINĀTNĒ*
}

2005. gada 14. janvārī apritēja 90 gadu kopš akadēmiķa Solomona Hillera, Latvijas Organiskās sintēzes institūta dibinātāja un izveidotāja, piedzimšanas. Šodien pirmoreiz pasniedz Solomona Hillera balvu biomedicīnā, ko pērn iedibinājusi Latvijas ZA kopā ar firmu "Grindex", Organiskās sintēzes institūtu un LU Biomedicīnas pētījumu un studiju centru. Aprit arī 40 gadu kopš iznāk heterociklisko savienojumu ķīmijas žurnāls, kura dibinātājs un pirmais redaktors ir bijis Hillers. Viss tas mudina atcerēties Solomonu Hilleru, izvērtēt viṇa mūžu un atgādināt viṇa paliekamo devumu zinātnē, kīimijā un biomedicīnā, un Latvijas tautsaimniecības attīstībā. Šis veikums un pats Hillera vārds faktiski visus pēdējos 15 gadus bija ja nu ne gluži noklusēts, tad klusināts gan. Objektīvi vērtējot un pilnā mērā atzīstot neatkarỉbas laika pozitīvos veikumus, tomēr visus šos gadus ir notikusi Hillera ieceru da|ēja demontāža vai vismaz tālejoša diminuitīva transformācija. Tikai nupat sāk iezīmēties renesanse, varbūt gan citā līmenī, un Hillera vārds Latvijai atkal k]ūst aktuāls Eiropas, globalizācijas, inovatīvās ražošanas kontekstā, kad eksaktās zinātnes, ķīmija atgūst savu vietu un prestižu, palēnām, bet, cerams, uz paliekamu laiku.

Tã nu ir, ka daudzu ievērojamu personību - zinātnieku, politiķu - likteños iezīmējas Hēgela negācijas negãcijas likums, trīs fãzes - tēze, antitēze, sintēze. Tèze - ir tad, kad cilvēks darbojas, apliecina savu darāmo, apliecina sevi, kad viņu cildina, ce] uz pjedestāla. Tēze bija Hillera mūža pēdējie 10-20 gadi (kaut arī tad vinam bija ietekmīgi nelabvē|li un skaug̉i). Antitēze ir fãze, kad noliedz visu pagātni; pēc nāves izrādās, ka cildinātā persona darījusi tik daudz slikta, nosodāma, kaitīga, ka pat viņa vārdu pieminēt nebūtu vietā. Sintēze - tas ir vēstures spriedums, kurā tiek izsvērts labais un launais, noskaldīts liekais, laikmeta sārṇi, acumirklīgais, pašas personības negācijas, bet atstāts paliekošais. Katra no šīm trim fãzēm ir loǵiska un dibināta, vēsture rit pretrunu straumē.

Sava taisnība varētu būt dažu pazīstamu ķīmiķu paustajam visai kritiskajam viedoklim par akadēmiḳi Hilleru kā "nelietīgu, nepārtraukti intrig̉ējošu" konjunktūristu,

* Lekcija S. Hillera pieminas lasījumos 2005. g. 26. janvårī Latvijas Organiskās sintēzes institūtā. 
taču tas ir loti sašaurināts, primitīvs lietu skatījums. Ar šiem Hillera vêrtējumiem te un šodien polemizēt negrasos. Akadēmiķis Hillers bija spilgta, bet patiešãm pretrunīga personība, kura psihologiisko portretu, ètisko relatīvismu uzskicēt nav viegli, un šajā jubilejas reizē varbūt tas arī nebūtu darāms. Taču mūža pamatmeti būtu jāatgâdina, jo daudzi, varbūt pat vairākums klātesošo, aktīvā dzīvē un zinātnē ienã̀ca tad, kad Hillera vairs nebija.

Tātad Rīgā 1915. gada 14. janvārī (1. janvārĩ pẽc vecã stila) Ãrona Hillera gimenē piedzimst dēls Šlioma (ar šãdu vārdu figurē dokumentos lĩdz 1941. gadam), vēlāk Solomons. Vina têvvs Rīgā iecelojis no Grodṇas, māte - no Belostokas, tomēr tãs ir vāciski runājošas Rīgas ebreju aprindas. Ārons Hillers (1883-1941) bija ekonomists, vilnas eksperts, strādāja par tirdzniecības ag̉entu un gumijas izstrādājumu (galošu) veikalu vadītāju akciju sabiedrībā "Kvadrāts”. Pēc arhīva ziṇām, 1927. g. ar Latvijas Republikas Ministru kabineta 28. jūnija lēmumu viñš līdz ar sievu Rohu (otra sieva, S. Hillera pamāte) un dēlu Šliomu uzṇemts Latvijas pavalstniecỉbā. $\bar{A}$. Hilleram kremta, ka neraugoties uz savu izglītīibu un cand. oec. grādu viṇš nav spējis iegūt atbilstošu sabiedrisku stāvokli, tādēl arī savu dēlu viṇš centās ievirzìt praktiskā darbā (fabrikās "Feldhūns" un "Emolip").

Taču 1933. gadā pēc Rīgas vācu komercvidusskolas absolvēšanas, pretēji tēva gribai, jaunais Hillers iestājas LU Ḳimijas fakultātē un II kursā sāk līdzdarboties organiskās ķīmijas seminārā, ko vada privātdocents Pauls Kalniṇš (1886-1955), Nobela prēmijas laureāta Friča Bergiusa kādreizējais laborants, cilvēks ar strīđīgām, tālejošām idejām, kuru vairums gan izrādījuš̃ās pārsteidzīgas un palikušas neīstenotas. Atšķirīibā no Gustava Vanaga Paulam Kalniṇam tikpat kā nebija skolnieku, taču viens no pavisam nedaudzajiem bija Solomons Hillers.

Jaunības gados Solomons Hillers organizēja un vadijja kreisi noskaņoto ebreju jauniešu intelektuā|u pulciṇu - Alanik (Allgemein anregendes Jugendkreis), kurā līdzdarbojās Mavriks Vulfsons, Jāzeps Eiduss, Juris Vaters un citi vēlāk vēsturē pazīstami cilvēki. Savā pê̄c nāves izdotajā grāmatā "Pagājība. Atskats un vērtējums" (Rīga, 2004) to nupat objektīvi aplūko prof. Eiduss. Šs pulcinšs veicināja Hillera daudzpusību, erudīciju un tuvināja viṇu kreisām, komunistiskām aprindām, taču ists, ortodokss komunists Hillers nav bijis. Ja viṇam būtu lemts darboties citos apstāklos, viṇš būtu visai veiksmīgs kapitālists, kā to jau savulaik ar ironiju atzina pazīstamais Maskavas k̦īmiķis prof. Aleksejs Kosts.

1941. gadā 27. jūnijā, vienā no pirmajām kara dienām, artilērijai grandot, S. Hillers aizstāv Paula Kalniṇa vadībā izstrādāto diplomdarbu par Langenbeka vielas struktûru un pēc izzinas saṇemšanas tūdal bēg no Rīgas, kur nāk iekšã hitlerieši. Holokaustā bojā gāja Rīgā palikušie S. Hillera tēvs, pamāte, māsa, visi pārējie tuvinieki. 1941.-1946. g. - darbs Sta|ingradas un Kazañas rūpnīcās, iepazī̌anās ar ražošanas procesiem. 1946. g. jūlijs - atgriešanās Rīgā, darbs nule dibinātajā Latvijas PSR Zinātṇu akadēmijā. Hillers kluva par Mežsaimniecības problēmu institūta jaunāko zinătnisko līdzstrādnieku un pēc tã direktora Arvīda Kalniṇa (1894-1981) ierosmes sāka pētīt pentozānsaturošo izejvielu ḳīmiskās izmantošanas iespējas. Pats Hillers izteicās, ka "zinātnē viṇš ir ienācis pa ḳeểa durvīm". Jo pētījumu izejas punkts no 


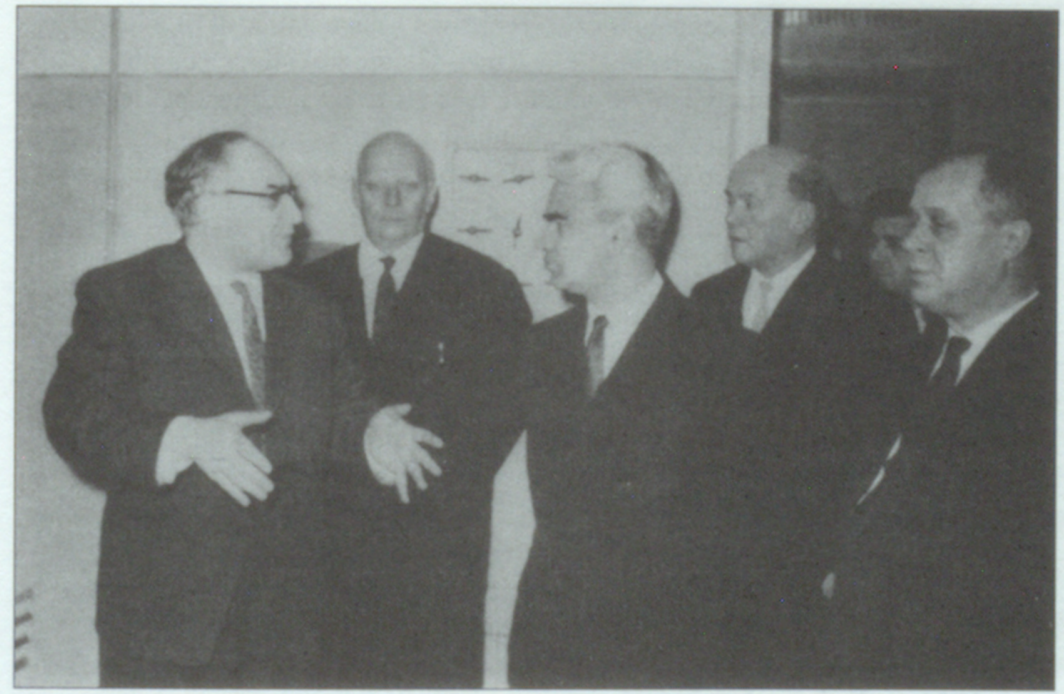

S. Hillers (pirmais no kreisās) jaunuzceltā Organiskās sintēzes institūta apmeklējuma reizē ar akadēmiḳiem A. Aleksandrovu, M. Keldišu, J. Peivi un PSRS Ministru Padomes priekšsēdētāja vietnieku S. Rudņevu 1962. gadā

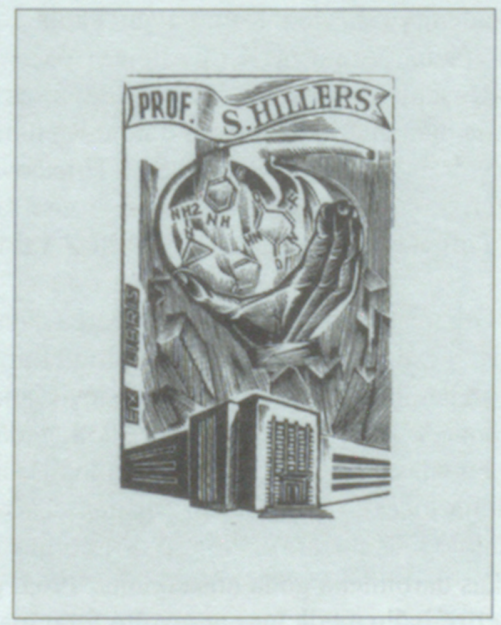

Solomona Hillera grāmatzīme (ar OSI ēku un S. Hillera pētīto vielu ķīmiskajām formulām) 
fundamentālās zinātnes viedok|a bija gauži prozaisks - augu valsts atkritumu vielu kukurūzas kacenu, saulgriežu čaumalu, koksnes skaidu, kokvilnas pogalu - utilizācija. Varēja šo problēmu risināt tīri utilitāri, taču Hilleram tas kluva par ieganstu, lai sāktu darbus organiskajā sintēzē, jaunu medikamentu iegūšanā. Jo augu valsts pentozāni ir galvenais furfurola avots, bet furfurolu ḳīmiski pārveidojot iegūstami ārstniecības līdzekli, pirmām kārtām, nitrofurāni, vēlāk - arī ftorafūrs. Pētot furfurolu, Rīgã pamazām izvērsusies furānu k̦īmija, vēlāk arī citu heterociklu kīmija, izvễrsusies medicīniskā k̦īmija, izvērsusies katalītiskā sintēze. Pateicoties Hillera ierosmei, Rīgā Latvijas PSR ZA 1955. g. izveidojās Pentozānsaturošo izejvielu pētî̌anas un izmantošanas vissavienības padome, kurai bija liela nozīme vēlākā Organiskās sintēzes institūta (OSI) tapšanā.

Tātad - S. Hillers Mežsaimniecības problēmu institūtā: 1949. g. - vecākais zinātniskais līdzstrādnieks; 1950. g. - furfurola sektora vadītājs; 1951. gadā Sta|ina prēmijas laureāts par līdzdalību prettuberkulozes preparāta PASS ražošanas izstrādē (tas bija pirmais Padomju Savienības mērogos pamanītais Latvijas zinātnieku panākums medicīniskajā ḳīmijā, kur lielāki nopelni varbūt bija ne Hilleram, bet studentam Leo Maijam, kas vēlāk izraisīja pēdējā konfliktu ar Hilleru); 1951. g. - ZA korespondētājloceklis (vēl pirms kandidāta disertācijas aizstāvēŠanas 1954. gada decembrī).

Hillers strauji virzijās pa karjeras kāpnēm, ebrejs Hillers - jau Stalina pusoficiālā antisemītisma gados, bet it īpaši Hruščova atkušṇa gados, mērḳtiecīgi virzījās ar sava institūta dibināšanu. Te savijās gan zinātniski, gan politiski momenti, subjektīvi un objektīvi momenti, - paša Hillera zinātniskais un organizatoriskais talants, prasme pãrliecināt, Maskavas un dažu Rīgas zinātnieku (tolaik - ZA prezidenta Jāna Peives, akadēmiḳu Arvīda Kalniṇa un Paula Stradiṇa) atbalsts un citu Rīgas zinātnieku (piem., Augusta Kirhenšteina) tikpat sparīgā pretestība, Hruščova iecerētā PSRS tautsaimniecības ḳimizācijas programma (gatavošanās PSKP CK 1958. g. Maija plēnumam), iecere veidot no Rietumiem neatkarīgu zālu industriju, zināmas decentralizācijas tendences PSRS Hruščova laikā, doma attīstīt zinātni arī valsts perifẽrijā, savienotajās republikās, - viss tas radīja fonu Organiskās sintēzes institūta oficiālai dibināšanai Latv. PSR ZA Prezidija sēdē 1956. g. 20. decembrī.

Tad nāk 1957. gads - Organiskās sintēzes institūta darba sākums. Hillers ir institūta pirmais direktors 181⁄2/2 gadu garumā. 1957. g. - pirmā Latvijas PSR Valsts prēmija par antimikrobu preparāta furacilīna sintēzi un ieviešanu medicīnā (kopā ar E. Gudrinieci, A. Kalniṇu, A. Blugeru, S. Zajevu); 1958. gadā - Latvijas PSR ZA akadēmiķis; 1963. g. - Latvijas PSR ZA K̦īmijas un biologijijas nodalas akadēmiḳis sekretârs un ZA Prezidija loceklis (koordinē 12 gadus visus republikã veicamos pêtijumus ḳīmijas un biologijas nozarē). 1965. g. - Latvijas PSR Nopelniem bagãtā zinātnes un tehnikas darbinieka goda nosaukums; 1965. g. vēl viena Latvijas PSR Valsts prēmija par originālu medicīnas preparātu furagīna un imifosa radīšanu un par vairāku citu preparātu ieviešanu ražošanā (kopã ar G. Vanagu, M. Līdaku, K. Venteru, A. Zīdermani u.c.). 1965. g. Vissavienības žurnāla "Heterociklisko 


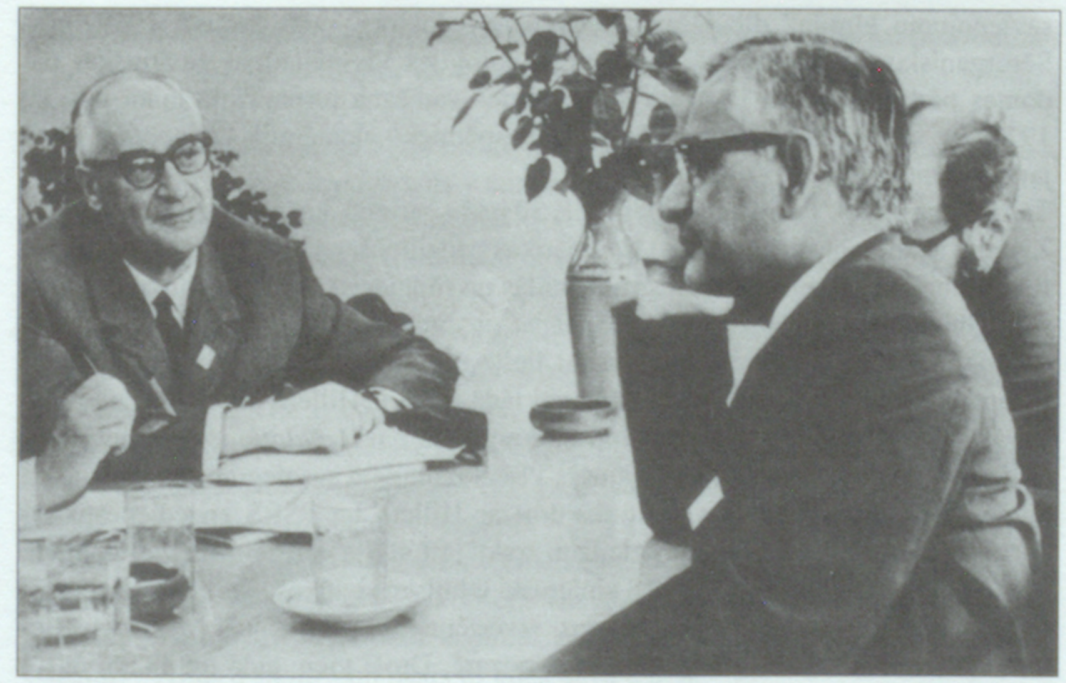

S. Hillers (pa kreisi) kopā ar Nobela prēmijas laureātu H.B. Koranu 7. Starptautiskā IUPAC dabasvielu k̦īmijas simpozija laikā (Rīgā, 1970. gada jūnijā)

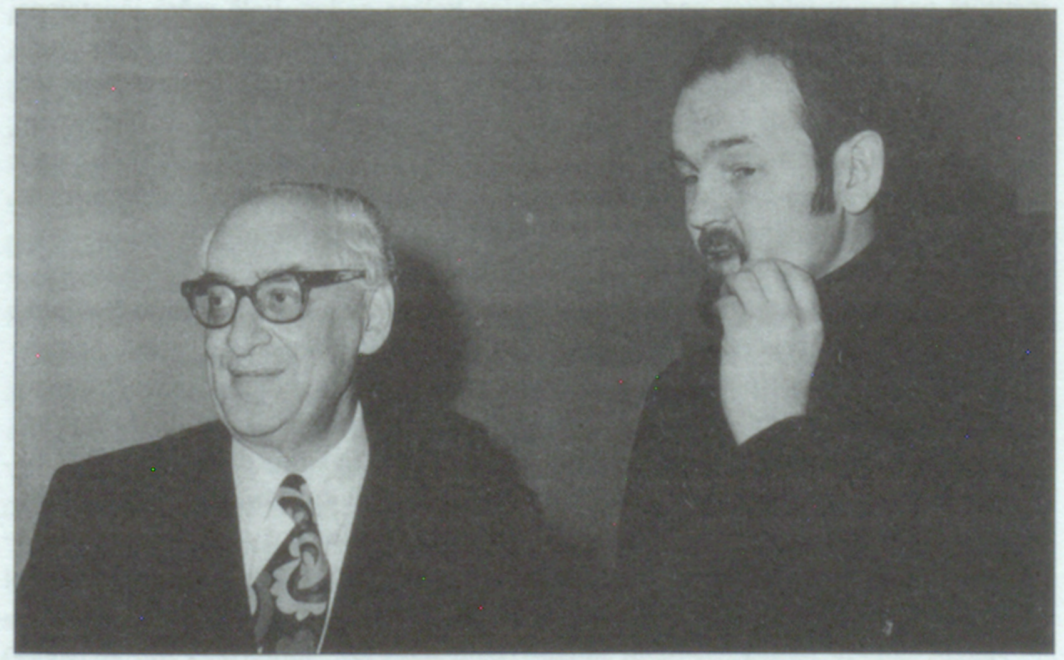

Organiskās sintēzes institūta direktors Solomons Hillers (pa kreisi) ar savu vietnieku Valdi Jākobsonu (tagad a/s Grindeks valdes priekšsēdētājs) 7. Starptautiskā IUPAC dabasvielu ķīmijas simpozija laikā 1970. gadā 
savienojumu k̦īmija" dibināšana (galvenais redaktors - 10 gadus); 1969. g. Sērorganisko savienojumu ḳīmijas un tehnolog̉ijas Vissavienības zinātniskās padomes pārbāzēšana uz Rīgu un šĩs padomes vadīšana turpmākajā laika posmā; 1972. g. - ievēlēšana slavenajā Vācu Dabaspētnieku akadēmijā "Leopoldina", tā jau ir starptautiska atzī̌ana.

Tāds, īsi savelkot, formāli ir Hillera ce|š 30 gadu garumā, kas iet līdztekus Latvijas Zinātṇu akadēmijas izaugsmei, tās tematikas padzilināšanai, paplašināšanai, transformēšanai, tās pētnieciskās, instrumentālās un rūpnieciskās bāzes pilnveidošanai, rezultātu ieviešanai tautsaimniecībā, tāpat ar zinātni saistītās rūpniecības izveidošanai Rīgā un arī Olainē (tomēr abi lielie 60. un 70. gados dibinātie Olaines giganti - Biolar un Olainfarm - šādā vai tādā mērā ir Hillera iniciatīvas un Maskavas sakaru rezultāts). Šis nopelnu uzskaitījums nav Laudatio, slavinājums, ne Hilleram, ne nu jau nebūtībā aizgājušās PSRS reālajiem sasniegumiem zinātnē un tehnologijiā. Primitīvi lietas būtu skaidrot ar Hillera un PSRS specdienestu sadarbības rezultātu, kā procesu palaikam traktēja Latvijas presē pirms 10 gadiem, atestējot OSI bezmaz vai kā PSRS zinātniski tehniskās izlūkošanas centru, kas esot darbojies VDK vadībā un kura eksperti izvērtējuši un piegādājuši Maskavai Rietumu pasaules informācijas analīzi savā nozarē. Droši vien, tãdā totalitārā valstī, kā Padomju Savienība, arī šādiem momentiem bija sava loma, institūtā strādāja arī isti čekisti, taču diez vai šis moments būtu izvirzāms priekšplānā. Ja toreizējā Padomju Latvijā būtu vairāk tādu "čekistu" kā Hillers, mēs savā tagadējā gaitā uz Eiropu būtu tikuši daudz tālāk. Arī par samērā liberālo, brīvdomīgo gaisotni institūtā padomju iekārtas gados, smacīgajos Pelšes gados, lielā mērā jāpateicas Hilleram. Būtībā - lai izvērtētu Hilleru, būtu jāizvērtē sovjetiskā režīma gadi Latvijas zinātnē, zaudējumi, guvumi, iespējas, arī nepiepildītās, jāvērtē zinātnes funkcionēšanas dažădi konteksti. Jāpiemin Hillera ciešie kontakti ar Maskavas zinātnisko eliti, bieži apejot Rīgu; nav jānoklusē arī ne pārāk ètiskā rīcība pret dažiem kolēgiem, kā Gustavu Vanagu, Arvīdu Kalniṇu viṇu mũža pēdējā posmā, tāpat pret jau pieminēto Leo Maiju. Viss ir bijis, tas pieder vēsturei.

Ja šaurāk izvērtē paša Hillera paliekamo devumu, tad tur iezīmējas 5 jomas:

1) Organiskās sintēzes institūta nodibināšana un izveidošana. Padomju Savienības ietvaros tas bija neparasts, progresīvi organizēts pētniecības centrs. Neraugoties uz visām peripetijām, tas joprojām pastāy un pilnveidojas, pēc nepilniem 2 gadiem atzīmēs 50 gadu jubileju, joprojām darbinieku skaita un varbūt arī rezultativitātes ziṇā ir lielākais pētnieciskais kolektīvs mūsdienu Latvijā. Domāju, tas nebūs subjektīvs viedoklis, ja sacīšu, ka 20. gs. otrajā pusē tas ir bijis pasaulē visatzītākais un vistālāk aizskanējušais pētniecíbas centrs Latvijā (kas 70.-80. gados Latvijā deva 66-70\% visu SCI citējamo rakstu!) - ne tikai ḳimijā, bet arī biomedicīnā (life sciences). Arī pašreiz laikam tas ir viens no visspēcīgākajiem pētnieciskajiem kolektīviem, kaut arī vairāk darbojas lietišḳās jomās, pat vairāk nekā Hillera laikā. Bet vispār - institūtā, Hillera laikā un arī vēlāk perfekti ir bijuši vienoti zinātniski pētnieciskie (fundamentālie) un lietišķie aspekti. 
2) Pētniecība heterociklu ķīmijā un tai tuvajās nozarēs (furānu ḳīmija, pirimidīnu un purīnu ķīmija, aziridīnu ķīmija, heterociklu žurnāls, plaša mēroga konferences).

3) Jaunu fiziologiski aktīvu vielu meklējumi visplašākajā aspektā un attiecīgu ražošanas tehnologiju izveidošana - antibakteriāli, pretvīrusu, pretvēža, psihofarmakologiski, kardiovaskulāri agenti (tie joprojām turpinās), arī lauksaimniecības ḳimizācijas līdzekli, insekticīdi, zoocīdi (PSRS laikā arī tiem bija būtiska nozime).

4) Bioorganiskās k̦īmijas un molekulārās biologiijas pētījumu iniciēšana Latvijā (galu galā OSI ietvaros izauga šĩs nozares akadēmiḳi G. Čipēns, E. Grēns, P. Pumpēns, V. Kluša, arī G. Duburs, J. Freimanis).

5) Farmaceitiskās lielražošanas izveidošana Latvijā - no OSI Eksperimentālās rūpnīcas, kas ir Hillera lolojums, 1991. gadā izauga firma "Grindex", tās priekšgalā arī ir Hillera uzticams audzēknis - Valdis Jākobsons, kurš Hillera mūža laikā (kopš 1965. gada) bija viṇa vietnieks administratīvi saimnieciskajos jautājumos OSI. Manuprāt, V. Jākobsons (arī Paula Stradiṇa balvas laureāts!) ir viens no izcilākajiem Hillera skolniekiem un darba turpinātājiem, kurš OSI izgājis "Hillera skolu" un nesis to tālāk savā darbā.

No Hillera vadībā izstrādātajiem medicīnas preparātiem bez jau pieminểtajiem furacilīna un $p$ - aminosalicilskābes (kas, saprotams, nebija origināli, bet resintezēti preparāti, un ārzemēs jau pazīstamu preparātu resintēze prevalēja arī turpmāk) minami furagìns un solafưrs (urologijāa, pret bakteriālām infekcijām, sepsi), imifoss - pret eritrēmiju, muskulu relaksants dioksonijs, pretgripas preparāts remantadīns, slavenais oriğinālais pretvēža preparāts ftorafūrs (tegafūrs), ko Hillers izstrādāja kopā ar Marg̉eru Līdaku un Regīnu Žuku 1964.-1970. g. Šo preparātu joprojām lieto Japānā un vienīgais no Latvijas zinātnieku atklājumiem tas ir iekłauts ķīmijas enciklopēdijās un lielās farmācijas grāmatās. Arī pie kardiovaskulārā preparāta mildronāts (pirmais nosaukums - kvaterīns) šūpula sava mūža pašā norietā stāvēja Hillers, pirmajā šĩ preparāta patentā līdzautoru skaitā ir arī S. Hillers. Š̀ preparāta galvenais autors ir akadēmiḳis Ivars Kalviņš̌, tolaik S. Hillera aspirants, kurš par šo izcilo sasniegumu, pašreizējo līderpreparātu "Grindex" produkcijā (ap $60 \%$ no firmas eksportprodukcijas) saṇem pirmo Solomona Hillera balvu.

Mildronāta jeb kvaterīna ideja radās OSI, kad 1970. gadā institūts saṇēma uzdevumu - utilizēt 1,1-dimetilhidrazīnu, raķešu degvielas ražošanas atkritumproduktu, kas militārajos poligonos pie Irkutskas bija uzkrājies tūkstošiem tonnu. "Slēgtajos" (slepenajos) pētijumos I. Kalviṇš daudzu gadu garumā kopā ar kolēgiem izstrādāja preparātu leakadīnu onkoloǵijai un mildronātu kardiovaskulāro slimību ārstēšanai, atkal oriǵinālpreparātu. Pirmā autorapliecība par mildronātu (kvaterīnu) tika izsniegta 1975. gada 14. janvārī (tieši Hillera dzimšanas dienā) tā bija it kã dāvana viṇam 60 gadu jubilejas reizē. Un atkal atkritumvielas utilizācijas nepieciešamība (kā tas ḳīmijā mēdz būt) 30 gadu garumā novedusi pie populāra orig̀ināla ârstniecības lĩdzek|a izveides. 
Taču arī pret ārzemēs pazīstamu preparātu resintēzi nebūtu jāizturas augstprātīgi vīpsnājot - arī tas nebija viegls darbs, un toreizējos PSRS izolācijas apstāklos tam bija milzu nozīme, arī Latvijas medicīnai, jo ārzemju preparāti nebija plašăk pieejami pacientiem - tie paši prettuberkulozes preparāti vai tio-TEFA ir glābuši cilvēku dzīvības.

Šajā reizē kaut pāris vārdi jāpasaka arī par Hillera iedibināto starptautisko žurnālu "Heterociklisko savienojumu ḳimija", kura pirmais numurs iznācis tieši pirms 40 gadiem 1965. g. februārī. Jau kopš 1965. gada paralēli pamatversijai krievu valodā šis žurnāls iznāk arī ASV "from cover to cover" un arī pašreiz to turpina izdot firma "Springer", pilnībā subsidējot gan anglu versiju, gan elektronisko versiju, gan lielā mērā arī krievu versiju. Pašreiz tas ir visvairāk citētais krievu valodā iznākošais ḳīmijas žurnāls pasaulē (atskaitot "Uspekhi khimii"), savulaik tas ieṇēma trešo vietu PSRS žurnālu starpā un 16. vietu pasaules zinātnisko žurnālu starpā jaunaprakstīto organisko savienojumu skaita ziṇā. Hillers vadīja žurnālu pirmos desmit gadus, izveidoja to, pēc tam desmit gadus (1975-1985) žurnālu bija uzticēts vadīt man, bet kopš 1985. gada žurnālu vada akadēmiḳis Edmunds Lukevics, priekšzīmīgs redaktors, rūpējoties gan par apskata rakstiem, gan par oriğinālrakstiem. Būtībā žurnāls ir OSI, Maskavas Valsts universitātes un N. Zẹinska Organiskās ķīmijas institūta kopprojekts. 2005. gada 1. numurs ir veltīts gan Hillera piemiṇai, gan žurnāla jubilejai, gan arī M. Lomonosova MVU 250 gadu jubilejai, kas nupat tika svin̄igi atzīmēta "Tatjanas dienā", 25. janvārī . Domāju, ka Organiskās sintēzes institūts var lepoties ar šo zinātnisko žurnālu, kas vienīgais no Latvijā iznākošajiem gandrīz no pastāvēšanas sākuma ir Gārfilda SCI datu bāzē. Pie žurnāla šūpu|a stāvējuši arī tādi ķīmiķi - organiḳi kā J. Jurjevs, A. Kosts, G. Vanags, I. Postovskis, M. Voronkovs, M. Līdaka, tagad redakcijas padomē ieklauti A. Katrickis, H. Vanderplāss, E. Vedējs, N. Zefirovs, N. Kočetkovs, V. Minkins. Gribu piebilst, ka Hillers pats joprojām tiek samērā plaši citēts ḳīmijas literatūrā. 2001.-2004. g. publikācijas ar viṇu kā pirmo autoru citẽ vairāk nekā 200 reižu, bet 1967. g. "Doklady Akademii nauk SSR" publicētais raksts (Hillers S., Žuka R., Līdaks M. Analogues of pyrimidine nucleosides. I. $N$-Alphafuranidinyl derivatives of natural pyrimidine bases and their antimetabolites), t.i. pirmpublikācija par ftorafūru tiek citēta 163 reizes! Vēl citē darbu par silēšanu ftorafưra ieguvē un kopā ar Ilonu Mažeiku veikto darbu par $\mathrm{N}$ - heterociklu dipolmomentu aprēḳiniem. Šĩ citêjamība ir prāva, tas liecina, ka vēl šodien Hillera darbi turpina tieš̌i ietekmēt zinātni.

Man ir patiess prieks, ka S. Hillera tuvākā līdzgaitniece ftorafūra radī̌̌anā Regīna Žuka šodien, šajā sēdē saṇem Latvijas ZA ārzemju locekles diplomu. Tas viṇai pieškîirts jau 2000. gadā, R. Žuka pašreiz strādā Izraēlā, Rehovotā farmaceitiskā firmā (H. Veicmaṇa institūta Tehnologiskā centra ietvaros), un ir zīmīgi, ka diplomu viṇa saṇem šajā reizēe un vietā, kur ir radīts ftorafūrs 1964. gadā, kur ir pagājušas viṇas mūža radošākie gadi. Arī skolnieki ir Hillera mantojuma da|̣a.

Hillers pats pavisam ir bijis aptuveni 300 zinātnisku rakstu, 80 autorapliecību un 40 ārzemju patentu līdzautors. Viṇa vadībā aizstâvêtas 30 kandidāta disertācijas, 
viņš ir bijis 6 doktora disertāciju zinātniskais konsultants. Hillera vadībā disertācijas, citu starpā, ir aizstāvējuši: LZA goda locekle Marija Šimanska, akadēmiķi Marg̀ers Līdaka, Ivars Kalviṇš, Edvards Liepiṇš, Jānis Stradiṇš, ZA ārzemju locekle Regīna Žuka, ZA korespondētājloceklis Grigorijs Veinbergs, ḳīmijas doktori Kārlis Venters, N̦ina Saldābola, Jānis Polis, Georgs Sokolovs, Valentīna Slavinska, Vitolds Egerts, Anatolijs Jeremejevs, Romualds Gavars, Ilona Mažeika, Laura Avota, Alnis Avots u.c. Viņš ir konsultējis arī mediķu Ainas Zīdermanes un Agra Ķimeṇa doktora disertācijas. Daudzi no minētajiem kolēgiem ir beiguši aktīvas darba, daži - pat mūža gaitas, tomēr daudzi joprojām ir aktīvi un ietekmē zinātni Latvijā.

Tāpat Hillers savulaik Rīgu darīja zinātnes pasaulē pazīstamu kā izcilu zinātnisku pasākumu norises vietu. No šiem saietiem visplašākais - unikāls un ievērots pasaules mērogā bija VII Starptautiskais IUPAC Dabasvielu ḳimijas simpozijs ar 4 presimpozijiem. Dalībnieku kopskaits tajā bija 1800, ieskaitot 4 Nobela prēmijas laureātus, plenārsēdes notika toreiz jaunuzceltajā hokeja hallē. Šajā simpozijā H.G. Korana pirmoreiz ziņoja par mākslīga gēna totālu sintēzi. Simpozijs notika 1970. gada jūnijā, līdzīga mēroga un nozīmības zinātniski pasākumi Rīgā nav rīkoti ne agrāk, ne arī vēlāk.

Pēdējie mūža gadi - ar lielajām konferencēm, ar ftorafūra iziešanu pasaulē līdz pat Japānai, ar aziridīna palēninātās inversijas parādību, ko 1972. gadā reǵistrēja kā PSRS “zinātnisku atklājumu" № 110, ar daudzajiem disertantiem un ārzemju braucieniem (ASV, Meksika, Zviedrija, Indija, Dienvidslāvija, Itālija, VDR, un, protams, Japāna) bija tāds kā Hillera darbības apogejs. Hillers tolaik neapstrīdami bija iestūrējis starptautiskos ūdeṇos. Vienlaikus viṇš bija daudzu zinātnes nozaru katalizators Latvijā, īpaši ķīmijā un biomedicīnā.

Beigas nāca tikpat pēkšñas, negaidītas, straujas, cik neparasts un pretrunīgs ir bijis Hillera mūžs. Tūdal pēc krāšñi nosvinētās 60 gadu jubilejas, Organiskās sintēzes institūtā, šajā pašã zālē, kurā kopā ar citiem izcilākajiem PSRS zinātniekiem vinuu sveica arī pazīstamais ķirurgs onkologs, toreizējais PSRS Medicīnas Zinātṇu akadēmijas prezidents prof. Nikolajs Blohins, Hillers devās uz Maskavu pie tã paša Blohina, lai viṇam izoperētu laundabīgu zarnu audzēju. Liktenis bieži ironizē, šoreiz tas Hilleram bija uzsūtījis launu kaiti, pret kuru vin̄š bija vêrsies ar visu savu mūža pētniecību. Ftorafürs nelīdzēja savam autoram, lielās mokās vinš mira 1975. g. 6. jūnijā, Linezera slimnīcā, tikai 60 gadu vecs. Patologanatomiskā sekcija tomēr rehabilitēja ftorafūru - primārais maligno šūnu perēklis bija rodams aizkuṇga dziedzerī, kura ārstēšanā preparāts nebija indicēts.

I Hillera lasījumos 1976. gadā savu lekciju par Hilleru nobeidzu ar šādu izskaṇu: "Solomons Hillers ir bijis vesels laikmets Latvijas ķīmijas un farmācijas vēsturē to varam sacīt pavisam droši jau šodien. Vai tas ir bijis zelta laikmets Latvijas ķ̄mijā vai prelūdija zelta laikmetam, to vēl nezinām, to uzzināsim pēc 20-30 gadiem. Taču man liekas - gan paša Hillera garam, gan mūsu vēsturiskā optimisma filozofijai vairāk atbilstu tēze, ka institūtu galvenais tomēr vēl gaida nākotnē. Latvijas ķimiķiem ir liels spēks, tiem jâmeklē jauni celi organiskajā ķīmijā, medicīniskajā 
ķīmijā, fizikālajā ķīmijā, bioorganiskajā ķīmijā, molekulārajā biologiijā. Solomons Hillers ir radìjis pamatu, vina pēcteču uzdevums - izmantot, pilnveidot to. Tã un tikai tâ varam godināt Solomonu Hilleru, lielo rïdzinieku Sergeja Eizenšteina, Frìdriha Candera un Vilhelma Ostvalda gara lïdzinieku."

Vēsture varbūt ir bijusi piesardzīgāka nekā citātā iek|autā doma, taču arī š̄isdienas referātu vēlētos nobeigt ar optimistisku izskaṇu un cerību pilnu skatu nākotnē. Ticu, ka arī joprojām pasaules ḳīmijā Latvija, Organiskās sintēzes institūts paliks un būs tā vieta, kur kaut kas notiek, notiek kaut kas nozīmīgs.

Jau kopš 1990. gada Organiskās sintēzes institūts piešķir savu augstāko apbalvojumu - Solomona Hillera medalu, tâdas piešksirtas jau 70, un šodien medalu sanēmēju pulkam pievienojas vēl trīs Hillera kādreizējās līdzgaitnieces dažãdās jomās - habilitētā doktore L. Leite (organiskā katalīze), ķīmijas doktore D. Lo|a (furānu nitrēšana) un heterociklu žurnāla atbildīgã sekretāre A. Skorova. Bet šī diena ir visai īpaša tajā zin̄ā, ka pirmoreiz tiek pasniegta Solomona Hillera balva, un to pelnīti saṇem tagadējais OSI direktors akadēmiḳis I. Kalvin̄š. Ierosinājumu iedibināt Solomona Hillera balvu izvirzijām jau 1975. gada jūnijā toreizējai Latvijas PSR Ministru Padomei un LPSR ZA Prezidijam. Ierosinājumu tolaik neatbalstīja, pat ZA Prezidija līmenī, - bija jāpaiet gandrīz 30 gadiem, lai to akceptētu LZA Senāts un istenotu ar firmas "Grindex" finansiālu atbalstu. Nu šĩ reize ir pienākusi, un lai tas ir vēl viens apliecinājums Latvijas ḳimijas un biomedicīnas zinātnes harmoniskai attīstībai.

Bet S. Hillera personiskais arhīvs un viṇam veltītā nelielā memoriālmuzeja (OSI) materiāli 2004. gadā nodoti Paula Stradiṇa Medicīnas vēstures muzejam, resp. Farmācijas muzejam, un es iedrošinos cerēt, ka tie tiks pētīti, vērtēti, sijāti arī nākamībai. Lai zinātnes gaita Latvijā neapstătos.

\section{Literatūra}

1. С.А. Гиллер: Жизнь и научная деятельность/ Сост. и отв. ред. Я. Страдынь. - Рига: Зинатне, 1982. - 392 с.

2. Страдынь Я. Симпозиум-дискуссия о молекулярно-биологических и биохимических принципах создания новых физиологически активных соединений // Изв. АН ЛатвССР. - 1975. - № 5. - С. 139-141.

3. Ордена Трудового Красного Знамени Институт органического синтеза Академии наук Латвийской ССР: Хронологический и систематический указатель трудов (1957-1971). - Рига, 1974. - 399 с.

4. Академик С.А. Гиллер: Биобиблиография/ Сост. Е.Я. Пейле и И.Я. Рейнис. -Рига: Зинатне, 1967.-129 с.

5. Ордена Трудового Красного Знамени Институт органического синтеза, 1957-1969./ Под. ред. С.А. Гиллера. - Рига: Зинатне, 1970. - 159 с.; 2-е изд. - Рига: Зинатне, 1972. - 152 c.

6. ОрденаТрудового Красного Знамени Институт органического синтеза, 1957-1976. Под. ред. Э.Я. Лукевица. - Рига: Зинатне, 1977. - 177 с.

7. Гиллер С.А. Конструирование лекарств// Наукаи человечество, 1968. Международный ежегодник - доступно и точно о главном в мировой науке. - Москва, 1968. С. $368-383$. 
8. Plenary lectures presented at the $7^{\text {th }}$ International Symposium on the Chemistry of Natural Products held at Riga, USSR, 22-27 June 1970/ Ed. M. N. Kolosov. - London: Butterworths, 1971. 304 p. (Pure and Appl. Chem. 1971, vol. 25, No. 1).

9. Скорова А.Э. Химия и технология органических соединений серы и сернистых соединений нефтей: Сессия в Риге// Вестник АН СССР. - № 6. - 110-112 (1972).

10. Гиллер С.А. Актуальнные проблемы химии и технологии органических соединений серы в СССР// Изучение и использование гетероатомных компонентов сернистых нефтей. - Рига: Зинатне, 1976. - С. 6-19.

11. Успехи химии фурана/ Под. ред. Э.Я. Лукевица. - Рига: Зинатне, 1978. - 302 с.

12. [Я. Страдынь] Памяти Соломона Ароновича Гиллера [с библиографией всех научн. тр. акад. АН ЛатвССР С.А. Гиллера]// Химия Гетероциклических Соединений. 1976. - № 1. - С. 3-26

13. Гончарова И.Н. І чтения памяти С.А. Гиллера//Химия Гетероциклических Соединений. - 1976. - № 7. - С. 1004, 1005.

14. Лидак М.Ю. II мемориальные чтения академика С.А. Гиллера// Химия Гетероциклических Соединений. - 1978. - № 12. - С. 1697-1698.

15. Шиманская М.B. IV Гиллеровские чтения// Химия Гетероциклических Соединений. - 1982, - № 6. - C. 853.

16. S. Hiller Memorial Lectures. - Riga, Jan. 23, 1990; Riga, 1990.

17. Stradiṇš $J$. No Grinde|a līdz mūsdienām: Apceres par farmācijas tradīcijām un jaunu ărstniecības preparātu meklējumiem Latvijā, profesora Jãña Stradiṇa sakārtojumā. Rĩga: Nordik, 1996. - 360. Ipp. (par S. Hilleru un viṇa izveidoto Organiskās sintēzes institūtu 155.-272. Ipp.).

18. Страдынь Я. Вехи биографии и научной деятельности академика С.А. Гиллера // Химия Гетероциклических Соединений. - 2005. - № 1. - С. 21-30.

19. Страдынь Я. У истоков журнала “Химия Гетероциклических соединений" // Химия Гетероциклических Соединений. - 2005. - № 1. - С. 15-20.

20. Страдынь Я. Мемориальные чтения академика С.А. Гиллера // Химия Гетероциклических Соединений. - 2005. - № 2. - С. 466-468.

\section{Solomon A. Hiller and His Contribution to the Medical Chemistry (Summary) \\ By Jānis Stradiňš}

The guidelines of the biography and scientific activities of Professor Solomon A. Hiller (195-1975) are discussed. Solomon Hiller, Full member of the Academy of Sciences of the Latvian SSR (1958) and Deutsche Akademie der Naturforscher Leopoldina (1972) was a well known Latvian chemist, expert in developing of new medicals. He was the founder of the Latvian Institute of Organic Synthesis (1957, director: 1957-1975), which has been the leading center of this branch in the former USSR.

The institute has developed about 60 new pharmaceuticals ( $1 / 4$ of all original drugs, invented in the USSR), among them the most well known are the anticancer preparation Ftorafur (in Japan - Tegafur), cardioprotector Mildronate, antiviral preparation Remantadin e. a. S.A. Hiller has published about 300 articles on 
heterocyclic chemistry, organic catalysis etc., he is the author of 80 USSR author certificates and 40 patents. He founded in 1965 an international journal "Chemistry of Heterocyclic Compounds" ("Khimiya geterotsiklicheskikh soedinenii"), and was its editor - in - chief till 1975. He should be regarded as one of the originators of the company "Grindex", which arose in 1991 from the Experimental plant of the Institute. Complicated situations and details in the biography of this brilliant organizer of science have been analysed.

\section{Prof. Jānis Stradiñ̌̌,}

Latvijas Organiskãs Sintẽzes institūts

Rīga, 226006, Aizkraukles iela 21, Latvija 